\title{
PENINGKATAN KAWALAN BRITISH MELALUI PERJANJIAN PERLIS-BRITISH 1930 DAN PENGUKUHAN KUASA ELIT MELAYU
}

\author{
Azmah Abd Manaf \\ Azwan Ahmad
}

\begin{abstract}
The existence of Perlis as a state in Peninsular Malaysia shows a long history involving foreign powers and influence of the Siamese and the British. Perlis was part of Kedah and the politics of foreign powers had put Perlis as a new sovereign state with its ruler known as Raja. For most of the Malay states, British protectorate demonstrated poor command of the sultan or the ruler of the authority and administration of their respective states. But for Perlis, though terms of the agreement were not significantly different, the Perlis government, under the British protection had a positive impact in strengthening the Malay elite's power in the state administration. In creating a good relationship with the British, the Perlis's Malay elite, administrators managed to limit the British influence in the state administration. On the other hand, the British seemed to agree with the decisions by the Perlis's Malay elites in some occasions. This article also shows how the Islamic reformist movement influences the Perlis's Malay elites administrators. They used the ideas of the movement to strengthen their position in the state and in the eyes of the Malay community.
\end{abstract}

\section{Pengenalan}

Mengkaji sejarah negeri Perlis seumpama memisahkan batu-batu putih daripada beras, di mana batu-batu putih itulah sumber bagi 
sejarah Perlis, sedangkan beras merupakan sumber bagi sejarah Kedah. Pengkaji-pengkaji sejarah Perlis seperti Dato' Yazid Mat, Julie Tang Su Chin, Profesor Madya Mohd Isa Othman dan Zahari Hj. Adam merujuk kepada sejarah negeri asalnya iaitu Kedah dalam menulis sejarah negeri Perlis. Justeru boleh dikatakan bahawa sejarah negeri Perlis sebagai sebuah negeri yang berasingan masih perlu ditulis dan dibincangkan. Mengisi kekurangan itu, artikel ini cuba untuk membincangkan sejarah negeri Perlis secara berasingan dengan memberikan tumpuan kepada usaha-usaha pemerintah negeri itu dalam mengukuhkan kuasa mereka dan kedudukan negeri Perlis sebagai sebuah negeri yang berdaulat.

Artikel ini akan membincangkan latar belakang kepada termeterainya Perjanjian Perlis-British pada tahun 1930 yang menyebabkan Perlis secara rasminya telah menjadi negeri Melayu yang terakhir bernaung di bawah kerajaan British. Perjanjian ini secara tidak langsung telah membenarkan pihak British campur tangan dalam hal ehwal pentadbiran negeri Perlis. Walau bagaimanapun, tidak seperti di negeri-negeri Melayu yang lain, artikel ini akan memperlihatkan bagaimana naungan British tidak menjadikan kedudukan raja Perlis semakin lemah sebaliknya bertambah teguh biarpun hadirnya penasihat British dalam pentadbiran negeri.

Kebijaksanaan elit pentadbir Perlis akan dibincangkan dalam memastikan pengaruh British yang minimum dalam menentukan siapa yang seharusnya menjadi raja Perlis selepas Raja Syed Alwi dan juga dalam hal ehwal pentadbiran negeri pada tahun 1930 hingga 1945 apabila pengaruh golongan elit pemerintah yang bertindak sebagai pentadbir awam di negeri Perlis semakin menyerlah. Kehadiran mereka dalam sistem pentadbiran yang diperkenalkan oleh pihak British telah membentuk satu dimensi baru dalam pola hubungan rakyat dan pemerintah. Rakyat mula memberi kepercayaan dan keyakinan kepada golongan ini dalam memajukan negeri Perlis dan memandang tinggi terhadap golongan ini. Tambahan lagi golongan ini berdamping rapat dengan kerabat diraja Perlis dan pegawai British. Kewujudan nilai kepercayaan yang tinggi terhadap golongan ini menyebabkan rakyat tidak hanya bergantung harap kepada raja tetapi menganggap golongan ini sebagai pelindung yang berkesan dalam memelihara keamanan dan membangunkan negeri Perlis.

\section{Latar belakang kepada Perjanjian Perlis-British 1930}

Kelahiran Perlis sebagai sebuah negeri yang berdaulat bukanlah satu kebetulan sebaliknya hasil daripada peranan yang dimainkan oleh 
kuasa-kuasa asing iaitu Siam dan British. Sejarah Perlis bermula pada tahun 1839 apabila kerajaan Siam memutuskan untuk memecahkan Kedah kepada empat bahagian iaitu Kedah, Kubang Pasu, Setul dan Perlis, yang setiap satunya ditadbir oleh Gabenor yang dilantik oleh Maharaja Siam. Perlis ditadbir oleh Raja Long Krok yang dibantu oleh Syed Hussin Jamalullail. Apabila Raja Long Krok meninggal dunia, Perlis ditadbir oleh Syed Hussin atas perintah maharaja Siam. ${ }^{1}$ Tahun 1839 merupakan tahun yang sangat penting bagi jajahan Perlis kerana telah mempunyai unit politik yang tersendiri dengan mempunyai Gabenornya sendiri, yang telah diberi mandat pentadbiran oleh kerajaan Siam. ${ }^{2}$ Perlis berada di bawah jajahan Siam sehingga tahun 1909, dan apabila termeterainya perjanjian Bangkok ${ }^{3}$ antara kerajaan Siam dengan British, Perlis berada di bawah naungan tidak rasmi British. ${ }^{4}$

Hubungan golongan pemerintah Perlis dengan kuasa penaung seperti Siam dan British bertujuan mengukuhkan hegemoni politik keluarga Jamalullail dan memastikan kelangsungan kewujudan kerajaan Perlis. Sebaliknya, penaung seperti British cuba meluaskan pengaruhnya di negeri Perlis melalui peranan yang dilaksanakan oleh Penasihat British. Pada sudut ekonomi, Perlis bukanlah memberi faedah yang besar kepada pihak British, tetapi pada sudut politik, pengukuhan pengaruh British ke atas Perlis amat bermakna untuk mengelak pengaruh luar merebak ke Semenanjung Tanah Melayu, khususnya pergolakan yang berlaku ke atas Patani di Selatan Siam. Jelasnya, Perlis dianggap sebagai benteng keselamatan kepada British di Tanah Melayu. Terdapat usaha-usaha yang bersungguh oleh British melalui penasihatnya untuk meletakkan pengaruhnya secara berterusan ke atas negeri Perlis.

Perjanjian rasmi Perlis-British 1930 adalah signifikan kepada perubahan fungsi dan peranan golongan elit Melayu dalam politik dan pentadbiran negeri Perlis. Walaupun perjanjian tersebut mengesahkan kedudukan raja sebagai ketua negeri, tetapi wibawa dan peranannya tidak lagi bebas sepenuhnya. Sebaliknya suara dan cadangan golongan elit Melayu Perlis boleh mempengaruhi sama ada raja Perlis ataupun Penasihat British melalui keahlian mereka sebagai ahli Majlis Mesyuarat Negeri. Dalam pentadbiran baru, raja tidak lagi bebas membuat keputusan tetapi perlu mendapat sokongan ahli Majlis Mesyuarat Negeri yang anggotanya terdiri dari golongan elit Melayu.

... the value of collaborative elites in sustaining imperial control. In this context, the Malay Rulers can be seen as an example of such an elite, acting as a vital prop to British predominance on the Malay peninsula. Britain's policy of preserving the rights of such monarchs was no mere act of altruism. Indeed, the British adopted this polic because of the reciprocal 
benefits which she enjoyed by entering into collaborative relationships with traditional elites. ${ }^{5}$

Pada penghujung tahun 1929, kerajaan Perlis telah berjaya melangsaikan hutangnya dengan Negeri Melayu Bersekutu. ${ }^{6}$ Berikutan penyelesaian hutang tersebut, perkhidmatan Penasihat Kewangan British ${ }^{7}$ di Perlis telah berakhir dan bermakna negeri Perlis telah bebas dari sebarang ikatan dengan pihak British. Raja Perlis sebenarnya mempunyai ruang dan kesempatan untuk membebaskan Perlis daripada sebarang pengaruh British seterusnya "memerdekakan" Perlis. Walaupun perjanjian Bangkok 1909 memutuskan bahawa Perlis diserahkan sepenuhnya kepada pihak British, tetapi tiada perakuan rasmi daripada raja Perlis sehinggalah termeterai perjanjian Perlis - British $1930 .{ }^{8}$ Seperti mana yang dinyatakan oleh Emerson, "Dalam tahun 1909 Perlis telah masuk di bawah naungan British melalui persetiaan Inggeris-Siam yang memberikan jaminan iaitu Negeri-Negeri Melayu Bersekutu akan menyanggupi hutang Perlis kepada Siam. Tetapi tidak ada perjanjian yang berasingan telah dibuat antara Great Britain dengan Perlis. Oleh itu hak-hak Great Britain ke atas Perlis, adalah hak-hak yang ada pada Siam pada masa dahulunya dan mungkin boleh dianggap bahawa hak-hak itu tamat apabila Perlis menjelaskan ansuran hutangnya yang akhir kepada Negeri-Negeri Melayu Bersekutu dalam T.H 1348"9 (1929 Tahun Masihi).

Raja Syed Alwi tidak mengambil kesempatan untuk mendapat kedaulatan penuh untuk negeri Perlis. Walhal kedudukan keluarga Jamalullail dalam takhta kerajaan Perlis semakin kukuh dan terjamin. Selain itu, tiada lagi ancaman untuk menyerapkan semula Perlis ke dalam Kedah apabila pihak British secara rasminya mengiktiraf fungsi dan peranan Majlis Mesyuarat Negeri Perlis yang merupakan kuasa pentadbiran tertinggi yang dipengerusikan sendiri oleh Raja Perlis sejak dari tahun 1905 lagi. Walaupun ada kebimbangan seperti yang dinyatakan oleh Julie, bahawa terdapat cadangan daripada W.G Maxwell, Penasihat British di Kedah supaya disatukan pentadbiran Perlis dan Kedah. Maxwell berpendapat bahawa "This State should not remain permanently independent of Kedah. Its destiny must be to revert to its former position as part of Kedah." 10 Namun begitu, cadangan tersebut tidak mendapat sebarang reaksi daripada Pejabat Jajahan British. Malahan pihak British sendiri seboleh-bolehnya tidak mahu mencetuskan suasana yang boleh menjejaskan hubungannya dengan pemerintah tempatan di Perlis.

Jika dianalisis pernyataan Maxwell, beliau sebenarnya tidak bermaksud untuk menyerapkan semula Perlis ke dalam Kedah, tetapi sebaliknya menyarankan satu bentuk "desentralisasi" Kedah-Perlis 
yang melibatkan Jabatan Pos dan Telegraf sebagai langkah penjimatan perbelanjaan. ${ }^{11}$ Apatah lagi, Perlis merupakan sebuah negeri bersaiz kecil dan tidak memerlukan Jabatan Pos dan Telegraf yang berasingan daripada Kedah. Malahan Maxwell menjelaskan bahawa "Perlis now uses the Kedah stamps, and all the postal and telegraphic forms with the heading "Government of Kedah" are accepted there without any demur on the part of the Perlis Government."12

Penerimaan penggunaan setem Kedah bukanlah bermakna Perlis menjadi sebahagian daripada negeri Kedah tetapi hanya melibatkan urusan Pos dan Telegraf sahaja. Sebaliknya penegasan mengenai kewujudan Perlis yang berasingan dengan Kedah telah diperakui oleh Maxwell sendiri apabila beliau menyatakan bahawa "The Raja and the State Council of Perlis are however wholly independent of the Sultan and the State Council of Kedah."13

Jelasnya, Maxwell tidak bermaksud untuk menyatukan semula Perlis ke dalam Kedah tetapi lebih kepada usaha pengagihan kuasa Perlis-Kedah yang melibatkan Jabatan Pos dan Telegraf. Maxwell sendiri sebenarnya merupakan salah seorang pegawai British yang terlibat dalam perancangan "desentralisasi" 14 yang cuba dilaksanakan oleh pihak British di Tanah Melayu sebelum Perang Dunia Ke-2. Selain itu, British tentu berhati-hati ${ }^{15}$ dalam menjalinkan hubungan dengan pemerintah tempatan dan seboleh-bolehnya mengelak daripada berlakunya sebarang konflik yang merugikan pihaknya. Selain itu, Maxwell tidak mempunyai hubungan yang baik dengan Kerabat Diraja Kedah dan ahli Majlis Mesyuarat Negeri Kedah ${ }^{16}$ tidak memungkinkan ada perbincangan dalam kalangan mereka untuk menyerapkan semula Perlis ke dalam Kedah melainkan usaha British melalui Maxwell untuk menarik negeri Perlis dan Kedah bergabung dengan Negeri Melayu Bersekutu.

Sebenarnya persoalan mengenai penggunaan setem Kedah dalam urusan surat menyurat negeri Perlis bukanlah merupakan "ancaman" untuk menyatukan semula Perlis ke dalam Kedah tetapi lebih kepada pengukuhan identiti Perlis sebagai sebuah negeri. Seperti mana yang disebut dalam surat Allen, Penasihat Kewangan Perlis kepada Penasihat Kedah yang bertarikh 24 Julai 1930 menyatakan:

I told the members of the Council that I had already considered the question of the revenue which might be expected from the sale of Perlis postage stamps and I did not think there would be much profit after deducting the expenses of the Posts and Telegraphs Department. The Raja immediately said that the desire for Perlis to have postage stamps of its own was not so much with a view to obtaining additional revenue as a desire that the stamps used in Perlis should bear the name of Perlis and not the name of another country. ${ }^{17}$ 
Tuntutan raja Perlis adalah berkenaan penggunaan setem negeri Perlis dalam urusan surat menyurat dan bukannya setem negeri Kedah walaupun hasil pendapatan daripada penggunaan setem dimasukkan ke dalam pendapatan kerajaan negeri Perlis berdasarkan urusan pos dan telegraf melalui Pejabat Pos dan Telegraf Kangar. ${ }^{18}$ Tuntutan raja Perlis telah ditolak oleh Pejabat Penasihat British di Kedah yang menegaskan "...Kedah Government is only prepared to continue present arrangement of conducting postal business in Perlis, provided that Kedah stamps are used as at present ${ }^{\prime 19} \mathrm{Hal}$ ini tidak bermakna bahawa Perlis berada di bawah penguasaan Kedah, tetapi langkah ini bertujuan untuk menyelaraskan urusan perkhidmatan pos dan telegraf bagi kedua-dua negeri dan pada masa yang sama sebagai langkah penjimatan. ${ }^{20}$

Tambahan pula, terdapat juga usaha-usaha ke arah menyatukan pentadbiran negeri Melayu Tidak Bersekutu dengan Negeri Melayu Bersekutu ke dalam satu pentadbiran Persekutuan sejak dari tahun 1920an lagi dan salah satu jabatan yang dipertimbangkan sebagai bidang kuasa kerajaan Persekutuan ialah Jabatan Pos dan Telegraf. Mengikut Emerson, penubuhan sebuah Lembaga Pos pusat akan mewakili Tanah Melayu sebagai satu unit dalam Kesatuan Pos dan menyelaraskan pelbagai kerja pentadbiran itu, menjadikan tiap-tiap negeri bebas menguruskan hal ehwal dalam negerinya sendiri dan mengeluarkan setem-setemnya sendiri. ${ }^{21}$

Langkah yang diambil sebenarnya membawa maksud bahawa negeri Perlis akan mempunyai setemnya sendiri apabila terlaksanakannya pembentukan sebuah Persekutuan Tanah Melayu. Selanjutnya Emerson berpendapat, langkah menubuhkan Lembaga Pos Pusat sebagai satu pelawaan umum kepada Tanah Jajahan dan negeri-negeri Melayu yang tidak bersekutu itu untuk masuk bersama-sama dengan Persekutuan dalam usaha-usaha tertentu yang akan dapat ditadbir dengan lebih cekap dan lebih ekonomik dengan berasaskan seluruh Tanah Melayu. ${ }^{22}$ Namun begitu, pada hakikatnya raja Perlis dan Raja-raja Negeri Melayu Tidak Bersekutu tidak berminat untuk menyertai Persekutuan memandangkan kedudukan mereka lebih baik berbanding raja-raja Melayu Negeri Melayu Bersekutu. Seperti mana jawapan yang diberikan oleh Maxwell, Penasihat Kedah kepada John Anderson, Pesuruhjaya Tinggi British di Singapura mengenai keengganan Negeri Melayu Tidak Bersekutu untuk menyertai Persektuan. Maxwell menegaskan tiga pertimbangan iaitu:

(a) the Ruler of an Unfederated State ruled, but the Ruler in the Federated States did not; (b) an Adviser in the U.M.S. paradoxically had more influence than the Resident in the F.M.S.; and (c) policy should aim at linking all the Malay States into "a loose-knit federation," wherein, each 
State can preserve its separate entity, its dignity and self-respect, whilst combining with all the other States in matters of common interest. ${ }^{23}$

Persoalan mengapa Raja Syed Alwi tidak berusaha untuk membebaskan Perlis daripada sebarang pengaruh kuasa British setelah penyelesaian pembayaran hutang negeri boleh dianalisis daripada beberapa aspek. Pertamanya desakan dan usaha Penasihat British, L. A. Allen supaya Raja Syed Alwi membuat perjanjian baru dengan pihak British setelah berakhirnya pembayaran hutang negeri Perlis, seperti mana yang dilaksanakan oleh Kedah pada tahun $1923 .{ }^{24}$ Allen telah berjaya mempengaruhi Raja Syed Alwi supaya "menjemput" British untuk terus menjadi penaung kepada Perlis. Pada 21 Januari 1929, Raja Syed Alwi telah menulis surat kepada Sir Hugh Clifford, Pesuruhjaya Tinggi British memaklumkan bahawa:

... the balance of the Perlis debt to the FMS is $\$ 50,000$, and that this amount will be paid in full in the year 1348 (1930). I am very grateful to my friend who has sent the various Advisers to help me in the successful accomplishment of the work of the country. If it can be arranged I am very anxious to remain under the Protection of Great Britain still. ${ }^{25}$

Sememangnya menjadi dasar British mempengaruhi raja-raja Melayu supaya menerima "protection" daripada pihaknya bagi memastikan kelangsungan penguasaan British ke atas negeri Melayu. Seperti mana yang dijelaskan oleh Abdul Rahman (1990) bahawa British tanpa kekecualian, didakyahkan sebagai telah dijemput ke Tanah Melayu untuk menaungi dan mengasuh negeri-negeri Melayu ke arah keamanan dan kemajuan. Kerana itu, bagi sebahagian orang-orang Melayu, seolaholah tidak timbul soal penjajahan British ke atas mereka. ${ }^{26}$

Melalui tindakan yang dilakukan, British berjaya memperlihatkan bahawa raja Perlis memohon kelangsungan naungan British ke atas negeri Perlis. Pada perkiraan rakyat, wujud kerjasama antara raja Perlis dan Penasihat British dalam memajukan Perlis sejak dari kehadiran Penasihat Kewangan British pada tahun 1909. Segala kemajuan dan pemodenan yang dibawa oleh British ke negeri Perlis itu memberikan satu bukti dan keyakinan kepada penduduk-penduduk negeri itu bahawa British tidak berniat untuk menjajah mereka, malahan bertujuan untuk membimbing. Hal ini lebih ketara lagi apabila mereka membandingkan zaman mereka dinaungi British dengan zaman mereka di bawah naungan Siam. ${ }^{27}$

Faktor kedua yang mendorong Raja Syed Alwi menandatangani Perjanjian Perlis-British pada tahun 1930, ialah kerana baginda beranggapan perjanjian tersebut berfaedah bagi memperkukuhkan 
kekuasaan baginda dan kesetiaan rakyat terhadap pemerintahan keluarga Jamalullail. Tambahan lagi perkara ke-6, Perjanjian PerlisBritish 1930 menyebut bahawa "The State of Perlis shall be governed by His Highness the Raja with the assistance of a State Council which shall consist of His Highness the Raja as President..." . ${ }^{28}$ Jelasnya, perkara ke-6 perjanjian tersebut memperlihatkan bahawa British secara rasmi mengesahkan kedudukan raja sebagai orang yang paling berkuasa dalam pemerintahan negeri dan mempunyai kuasa eksekutif dalam pentadbiran negeri Perlis. Selain itu perkara ke-4 perjanjian, memberi jaminan kepada kelangsungan pemerintahan keluarga Jamalullail terhadap pemerintahan negeri Perlis. Perkara ke-4 perjanjian berbunyi:

The successor to the Rajaship shall always be a direct descendent of His Highness Tuan Syed Alwi or, if there is no direct descendant, a descendant of his ancestors, chosen by the State Council and accepted by His Britannic Majesty... ${ }^{29}$

Keyakinan Raja Syed Alwi terhadap naungan British ke atas Perlis dapat dilihat pada titah ucapan baginda dalam Mesyuarat Majlis Negeri Perlis kali pertama selepas perjanjian tersebut iaitu pada 3 Mei 1930 yang berbunyi, "...kerana boleh tumpang bernaung di bawah kerajaan Great Britain kerana beta yakin bahawa kerajaan itulah yang sehabis besar dan adil sekali di dunia..." ${ }^{30}$

Naungan British telah mengukuhkan kedudukan raja dalam kalangan rakyat dan para pencabarnya. Raja Syed Alwi sebenarnya menyedari ancaman daripada Syed Hamzah ${ }^{31}$ yang menunggu ruang dan kesempatan untuk menjadi Raja Perlis. Tambahan lagi Raja Syed Alwi tidak mempunyai putera yang bakal mewarisi takhta Perlis. Selain itu, Syed Mahmud, Raja Muda Perlis telah terlucut jawatannya apabila didapati bersalah atas tuduhan berkhalwat dengan adik perempuannya pada tahun 1912 dan dipenjarakan selama lima tahun di Kedah. ${ }^{32}$

Sejak tahun 1912, jawatan Raja Muda belum diganti walaupun Syed Hamzah merupakan orang yang paling kanan untuk jawatan tersebut kerana Raja Syed Alwi masih berharap untuk mendapat anak lelaki ${ }^{33}$ selain perwatakan Syed Hamzah yang tidak baik. Dipercayai Syed Hamzah telah menekan Raja Syed Alwi supaya melantik dirinya sebagai bakal raja berdasarkan pengalaman pentadbiran eksekutif dan lebih-lebih lagi jawatannya sebagai naib Presiden Majlis Mesyuarat Negeri Perlis. ${ }^{34}$ Namun hasrat Syed Hamzah terhalang oleh perkara ke-4, iaitu: "... if there is no direct descendant, a descendant of his ancestors, chosen by the State Council and accepted by His Britannic Majesty. ${ }^{35}$ Ini bermakna Syed Hamzah perlu mendapat sokongan dari ahli Majlis Mesyuarat Negeri yang dipengerusikan oleh Raja Syed Alwi sendiri. 
Walaupun Syed Hamzah daripada kerabat diraja Perlis, tetapi beliau bukanlah calon popular dalam kalangan ahli Majlis Mesyuarat Negeri untuk menggantikan Syed Alwi selaku Raja Perlis.

Kedudukan Syed Hamzah sebagai kerabat diraja Perlis dan orang yang paling dekat ikatan kekeluargaan Raja Syed Alwi tidak lagi menjamin kelayakan untuk dilantik sebagai bakal raja atau Raja Muda. Walaupun bekas Penasihat Perlis seperti H. C. Eckhardt, P.S. Williams, dan L. A. Allen beranggapan bahawa Syed Hamzah sebagai seorang yang "intelligence, ability and occasional helpfulness", 36 dan banyak memberi sumbangan kepada pembangunan pendidikan ${ }^{37}$ serta perkembangan syiar Islam di Perlis, ${ }^{38}$ namun gagal mempengaruhi sokongan ahli Majlis Mesyuarat Negeri. Penolakan ahli Majlis mesyuarat negeri berikutan Syed Hamzah terlibat dengan aktiviti perjudian ${ }^{39}$ dan mempunyai hubungan dengan kongsi gelap Tuan Bulat. ${ }^{40}$

Syed Hamzah juga telah menubuhkan Sufian Club bersempena dengan nama puteranya iaitu Syed Sufian ${ }^{41}$ yang menjalankan aktiviti perjudian secara terbuka. ${ }^{42}$ Sufian Club beroperasi di sekitar Arau dan mempunyai bangunan rasmi untuk menjalankan perniagaan perjudian. ${ }^{43}$ Bangunan tersebut telah diambil alih pegawai Jepun semasa pendudukan Jepun di Perlis untuk tujuan pentadbiran. ${ }^{44}$ Penglibatan Syed Hamzah dengan aktiviti perjudian menyebabkan beliau berhutang sebanyak \$50,000 kepada Jagat Singh, ${ }^{45}$ seorang ceti yang beroperasi memberi pinjaman wang kepada penduduk, khususnya petani di sekitar Perlis. Sebenarnya telah ada tindakan buang negeri terhadap Jagat Singh melalui arahan yang dikeluarkan oleh Raja Perlis pada tahun 1915, tetapi arahan buang negeri telah ditarik baik pada tahun 1916.

Pada 5 November 1931, sekali lagi Jagat Singh dikenakan perintah buang negeri oleh Raja Perlis dengan persetujuan anggota Majlis Mesyuarat Negeri. ${ }^{46}$ Tindakan ini berikutan terdapat anggota kerabat diraja Perlis yang berhutang dengan Jagat Singh, iaitu keenam-enam orang adik perempuan Raja Syed Alwi selain Syed Hamzah sendiri. ${ }^{47}$ Jelasnya, kelemahan yang ada pada diri Syed Hamzah menjadi alasan paling munasabah kepada ahli majlis mesyuarat negeri untuk mempengaruhi Penasihat British menyingkir Syed Hamzah daripada calon bakal raja menggantikan Syed Alwi.

Perkara yang tidak boleh dinafikan dalam menjelaskan penolakan terhadap Syed Hamzah oleh pihak British ialah pengaruh daripada golongan elit pemerintah seperti Tuan Haji Muhammad Nor (Ketua Kadi), Tuan Haji Ahmad (Ketua Hakim), En. Wan Ahmad (Pegawai Syarikat Kerjasama) dan Syeikh Ahmad (Penolong Juruadit). Tuan Haji Muhammad Nor dan Haji Ahmad merupakan ahli Majlis Mesyuarat Negeri pada ketika pergolakan mengenai perlantikan bakal raja Perlis. Mereka berempat merupakan orang yang berpengaruh di negeri Perlis 
dan mempunyai hubungan yang baik dengan Raja Syed Alwi. Malahan Tuan Haji Ahmad merupakan orang kepercayaan Raja Syed Alwi, sehinggakan segala apa nasihatnya diterima oleh Raja Syed Alwi. ${ }^{48}$

Tuan Haji Ahmad dan Syeikh Ahmad merupakan orang yang paling bertanggungjawab dalam menjayakan pelantikan Syed Hassan ${ }^{49}$ sebagai bakal raja Perlis, di mana Tuan Haji Ahmad bekerja keras dan giat berusaha memujuk serta menasihati Raja Syed Alwi supaya mengangkat Tuan Syed Hassan sebagai bakal raja Perlis. ${ }^{50}$ Sementara Syeikh Ahmad berperanan dalam menpengaruhi O.E. Venables Penasihat British pada ketika untuk melantik Syed Hassan seperti mana yang diakui oleh Syeikh Ahmad iaitu“...Tuan Venables sangat baik dengan saya. Maka saya pun masuk campur dalam perkiraan Tuan Syed Hassan menjadi bakal raja." ${ }^{51}$

Pada 6 Disember 1934, Syed Hassan telah diputuskan sebagai bakal raja Perlis oleh Majlis Mesyuarat Negeri dengan sokongan Penasihat British. ${ }^{52}$ Apabila Syed Hassan meninggal dunia ${ }^{53}$ pada 18 Oktober 1935, sekali lagi Syed Hamzah diketepikan daripada dipilih menjadi bakal raja Perlis. Syed Hamzah bukan sahaja tidak mendapat sokongan daripada golongan elit Melayu seperti Tuan Haji Ahmad dan Tuan Mohammad Nor yang merupakan ahli Majlis Mesyuarat Negeri, tetapi juga O.E. Venables, Penasihat British dan Pesuruhjaya Tinggi British iaitu Shenton Thomas. ${ }^{54}$

Campur tangan golongan elit pemerintah telah berjaya menyingkirkan Syed Hamzah. Tuan Haji Ahmad dan Tuan Muhammad Nor merupakan anggota Majlis Mesyurat Negeri yang diberi kuasa menentukan pelantikan bakal raja Perlis. Sememangnya Tuan Haji Ahmad merupakan individu yang berpengaruh dan berjaya menyingkir Syed Hamzah daripada mendapat haknya sebagai bakal raja ${ }^{55}$ kerana Tuan Haji Ahmad berperanan dalam mempengaruhi Raja Syed Alwi untuk memilih Syed Hassan dan kemudiannya Syed Harun ${ }^{56}$ sebagai Bakal Raja Perlis. Seperti mana yang digambarkan oleh Syeikh Ahmad,..."Tuan Haji Ahmad sangat mengambil berat dan daya usaha yang tidak terhingga, maka dengan kebijaksanaan beliau, Almarhum Tuan Syed Alwi bersetuju melantik Tuan Syed Putra menjadi bakal raja mengganti Almarhum Tuan Syed Hassan bapanya. Maka dari semenjak itu Tuan Haji Ahmad sangat-sangat dibenci oleh Syed Hamzah." ${ }^{57}$

Kedudukan Syed Hamzah dalam Majlis Mesyuarat Negeri dan kerabat diraja Perlis tidak membantu beliau untuk menjadi bakal raja Perlis. Syed Hamzah sendiri tidak mempunyai alasan yang kuat selain dari kerabat terdekat kepada Raja Syed Alwi kerana beliau sendiri sebenarnya tidak pernah dilantik menjadi Raja Muda ${ }^{58}$ sejak dari kemangkatan Syed Mahmud, Raja Muda Perlis pada tahun 1919. 


\section{Pengukuhan Kuasa Raja Syed Alwi}

Sememangnya Perjanjian Perlis-British 1930, seolah-olah mengukuhkan kedudukan Raja Syed Alwi apabila individu atau kumpulan yang tidak diiktiraf tiada lagi peluang untuk mencabar raja atau pembesar yang dinaungi oleh British. Sama ada disedari atau tidak, Perjanjian Perlis-British 1930, telah berjaya meningkatkan pengaruh golongan elit pemerintah serta memperkukuh kawalan British melalui Penasihat British terhadap pentadbiran negeri Perlis. Merujuk kepada isu perlantikan bakal raja Perlis, pembesar ataupun golongan elit pemerintah dan Penasihat British telah berperanan dalam percaturan untuk penentuan siapa yang layak dipilih dan bukan lagi waris terdekat kepada Raja Syed Alwi sekiranya raja tidak mempunyai anak lelaki. Malah Raja Syed Alwi sebenarnya terikat dengan perkara ke-5 perjanjian yang menyebut:

.... B British Adviser to advise on all matters connected with the Government of the State other than matters relating to Malay custom or Mohemmedan religion, and will accept such advice. ${ }^{59}$

Berdasarkan perkara ke-5 Perjanjian Perlis-British 1930, raja dan penggantinya tidak lagi bebas dalam membuat keputusan tetapi perlu terlebih dahulu merujuk kepada nasihat Penasihat British. Hal ini telah menyempitkan medan wibawa baginda raja Perlis apabila kuasa beliau dibatasi oleh Penasihat British. ${ }^{60}$

Sebenarnya Perjanjian Perlis British 1930, lebih kepada operasi membentuk satu struktur kawalan ke atas pentadbiran Perlis melalui institusi raja dan pembesar (elit Melayu) yang menjadi simbol taat setia masyarakat Melayu. British cuba memperlihatkan watak yang baik, sebagai pelindung dan pembantu kepada raja dalam usaha memajukan pentadbiran negeri Perlis. Seperti mana yang didakwa oleh Sir Hugh Clifford, Pesuruhjaya Tinggi British pada tahun 1929, yang menggantikan Sir William Guillemard, bahawa:

The administration of any of the Unfederated Malay States must inevitably, in existing circumstances, be on a somewhat lower plane of efficiency than that of the Federated Malay States. It is our policy in the former to refrain, as far as possible, from taking the task of administration out of the hands of the Sultans and their officers by transferring it to Europeans, our object being to assist, guide and train the ruling classes of the indigenous population in the wise and just management of their own affairs. ${ }^{61}$

Peliknya, walaupun pentadbiran negeri Perlis dan Negeri Melayu Tidak Bersekutu yang lainnya dianggap berada pada tahap yang rendah berbanding Negeri Melayu Bersekutu, tetapi British mengakui bahawa 
Raja Perlis dan Sultan Negeri Melayu Tidak Bersekutu yang lain lebih berautoriti berbanding Negeri Melayu Bersekutu. Sebagai contoh negeri Kedah, yang Perlis asalnya sebahagian wilayahnya, dianggap mempunyai pentadbiran yang begitu sistematik dan moden ${ }^{62}$ seperti mana yang diakui oleh Allen dalam kajian "The elephant and mousedeer-a new version of Anglo-Kedah relation 1905-1915." " 63 Begitu juga Johor telah mencapai pomodenan pentadbiran yang diusahakan oleh Temenggung Ibrahim dan diteruskan oleh Maharaja Abu Bakar. ${ }^{64}$ Namun, doktrin British sebagai sahabat yang membantu pentadbiran Raja Melayu, menyebabkan masyarakat Melayu Perlis begitu yakin bahawa hanya British yang mampu memaju dan memodenkan negeri Perlis.

Malah British dilihat memenuhi semua tuntutan Raja Syed Alwi dalam merangka draf Perjanjian Perlis-British $1930^{65}$ dan memberi keutamaan kepada anak Melayu tempatan dan memartabatkan bahasa Melayu dalam pentadbiran negeri. Misalnya pada perkara ke-6, yeng menyebut:

The State of Perlis shall be governed by His Highness the Raja with the assistance of a State Council which shall consist of His Highness the Raja as President, three other Perlis Malay members selected... In the absence of His Highness a Malay member selected by His Highness shall preside over the Council,"66 perkara ke-7, yang berbunyi "The officers of the Government of Perlis shall be Perlis Malays, but if the State Council considers that there is any work which Perlis Malays are not capable of performing, then only will persons from outside be employed. The State Councill will send Perlis Malays to study outside various branches of learning... so that they may be use to Government of the State of Perlis," 67 serta perkara ke-8 yang menegaskan bahawa "The Malay language, with Jawi character in the case of written language, shall be the official language in all department of the Government of Perlis... ${ }^{68}$

Perlu disedari bahawa perkara ke-6, ke-7 dan ke-8, Perjanjian PerlisBritish 1930, sebenarnya menyamai model Perlembagaan Negeri Johor $1895^{69}$ dan Perjanjian Kedah British 1923. ${ }^{70}$ Kedua-dua negeri itu merupakan penentang kuat kepada cadangan menggabungkan Negeri Melayu Tidak Bersekutu dengan Negeri Melayu Bersekutu ke dalam Persekutuan Melayu. ${ }^{71}$ Tambahan lagi pada tahun 1920-an dan tahun 1930-an, isu kepentingan Melayu mula mendapat perhatian pihak British apabila usaha untuk menyatukan Negeri Selat bersama negeri Melayu Tidak Bersekutu dan Negeri Melayu Bersekutu menunjukkan bilangan penduduk bukan Melayu melebihi penduduk Melayu. ${ }^{72}$

Selain itu, timbul kerisauan dalam kalangan segolongan orang Melayu mengenai kemunduran orang Melayu dalam ekonomi dan pendidikan. Kerisauan ini disuarakan melalui Persatuan Guru Melayu, ${ }^{73}$ 
Majalah ${ }^{74}$ dan akhbar-akhbar, ${ }^{75}$ tentunya mendapat perhatian daripada pihak British. Oleh yang demikian, sebagai meredakan tekanan dan kebimbangan orang Melayu, British membina perjanjian yang dilihat melindungi kepentingan orang Melayu, seperti mana Perjanjian BritishKedah 1923 dan Perjanjian Perlis -British 1930.

Tidak dinafikan perkara ke-6, ke-7 dan ke-8, Perjanjian Perlis-British 1930 memberi ruang dan peluang kepada anak Melayu Perlis terlibat dalam pentadbiran kerajaan dan berpeluang mendapat pendidikan luar sebagai latihan persediaan untuk menjawat jawatan dalam perkhidmatan kerajaan. Namun hakikatnya, tidak ramai rakyat biasa yang berpeluang melanjutkan pelajaran ke peringkat yang lebih tinggi (melepasi darjah iv), walaupun untuk melayakkan diri untuk dilantik sebagai kerani bawahan. ${ }^{76}$ Sebaliknya British hanya mengutamakan golongan kerabat diraja Perlis, dan golongan elit Melayu yang berdamping rapat dengan pihak British. ${ }^{77}$ Tujuan pendidikan kepada orang Melayu sebelum perang dunia ke-2 lebih kepada menyediakan latihan kepada kerabat diraja dan elit Melayu sebagai pentadbir di negeri Perlis.

Sejak dari termeterai Perjanjian Perlis-British 1930 sehingga Perang Dunia Kedua, pengisian jawatan penting dalam pentadbiran kerajaan negeri diisi oleh golongan bangsawan dan elit Melayu yang berdamping rapat dengan kerabat diraja Perlis dan Penasihat British. Paling tinggi jawatan yang disandang oleh orang Melayu ialah Senior Officer Kelas Dua. Antara yang pernah mendapat taraf jawatan Senior Officer Kelas Dua, ialah Tuan Syed Hassan bin Syed Mahmud, Syeikh Ahmad dan Tuan Haji Ismail. ${ }^{78}$ Tokoh lain yang berpengaruh dalam pentadbiran kerajaan Perlis seperti Dato' Wan Ahmad bin Wan Daud, merupakan bendahari negeri Perlis dan pernah dilantik menjadi ahli Majlis Mesyuarat Negeri pada tahun 1938, ${ }^{79}$ Ahmad Haji Kassim (Tok Mat Chief), Ketua Polis Negeri Perlis, ${ }^{80}$ dan Tuan Haji Mohammad Nor bin Haji Mohammad, merupakan Kadi Besar Perlis dan bertanggungjawab dalam pentadbiran agama Islam di negeri Perlis, serta adiknya Tuan Haji Ahmad (Haji Mat Akim), Ketua Hakim dan telah dilantik menjadi ahli Majlis Mesyuarat Negeri pada tahun 1938. ${ }^{81}$

Mereka ini merupakan kumpulan elit Melayu yang mempunyai kedudukan yang tinggi pentadbiran kerajaan dan amat dihormati oleh masyarakat Melayu Perlis. Oleh kerana mereka rapat dengan Raja Syed Alwi dan golongan bangsawan, mereka telah "dihadiahkan" jawatan penting dalam kerajaan. Sebagai contoh, Tuan Haji Ahmad dan Wan Ahmad bin Wan Daud telah dilantik sebagai ahli Majlis Mesyuarat Negeri pada tahun 1938, kerana bukan sahaja mempunyai hubungan yang rapat dengan Raja Syed Alwi, malah dengan bakal raja iaitu, Syed Hassan dan Syed Putra. ${ }^{82}$ Apatah lagi mereka berperanan dalam 
menyingkirkan Syed Hamzah daripada jawatan bakal raja pada tahun 1935 dan 1938, dengan "restu" pihak British.

Hakikatnya, Perjanjian Perlis-British 1930 merupakan usaha British untuk menjadikan raja dan golongan elit Melayu sebagai sekutu yang erat dalam menjayakan kawalan politik, terhadap masyarakat Melayu Perlis. Pihak British berjaya mengambil hati raja dan elit Melayu Perlis dengan memberi mereka ganjaran dan kedudukan. Raja Perlis dan kerabat telah memperoleh jaminan pemberian elaun tetap sebagai sumber pendapatan seperti mana yang ditegaskan dalam perkara ke-4, Perjanjian Perlis- British 1930, yang menekankan bahawa:

...The Raja and his family shall be entitled to adequete support from the public funds of Perlis, the term family meaning the children of the Raja and those of grandchildren who are the children of his sons. ${ }^{83}$

Tambahan pula raja dan kerabat menghadapi masalah kewangan sehingga ada yang berhutang dengan kerajaan negeri dan ceti-ceti, ${ }^{84}$ dan pemberian elaun tetap sedikit sebanyak membantu menyelesaikan masalah kewangan raja dan kerabatnya. Kedudukan raja telah berubah menjadi orang makan gaji, apabila semua perbelanjaan rasmi ditanggung oleh kerajaan negeri. Baginda juga turut diberi kemudahankemudahan lain yang selesa seperti kereta dan istana rasmi. ${ }^{85}$ Sementara itu, golongan bangsawan dan elit Melayu Perlis diberi "penghormatan" menjawat jawatan tinggi dalam pentadbiran negeri sama ada sebagai ahli Majlis Mesyuarat Negeri ataupun mengetuai sesuatu jabatan. ${ }^{86}$ Mereka ini yang umumnya berpendidikan Inggeris, telah serasi dengan nilai-nilai dan kehendak Inggeris berperanan sebagai orang tengah yang boleh membantu melicinkan pemerintahan "penjajahan" British ke atas anak negeri.

Melalui penganugerahan jawatan dan kedudukan, raja dan elit Melayu Perlis sebenar telah disemai dengan perasaan ketaatan kepada British dan beranggapan bahawa British bukan sahaja berfungsi sebagai penaung kepada negeri Perlis, tetapi juga pelindung kepada pribumi Melayu Perlis. Oleh hal yang demikian adalah tidak menghairankan raja Perlis telah menyumbang sebanyak £500 kepada King George V National Memorial Fund yang dibuka di Mansion House, sempena pertabalan King George VI pada 12 Disember 1936 sebagai Maharaja Great Britain ke-6. Selain daripada itu, diadakan perayaan sambutan peringkat negeri sebagai tanda penghormatan dan taat setia kepada Maharaja Great Britain serta majlis bacaan doa di seluruh masjid negeri Perlis memohon supaya dikekalkan King George VI di atas tahkta kerajaan Great Britain. ${ }^{87}$ 
Hal ini membuktikan bahawa raja Perlis dan elit Melayu menerima baik pertuanan British ke atas negeri Perlis dan berusaha membina hubungan yang baik dengan kuasa penaungnya. Jelasnya, Perkara ke6, ke-7 dan ke-8, Perjanjian Perlis- British 1930 yang lebih merupakan dakyah-dakyah yang menonjolkan British sebagai pelindung kepada kepentingan orang Melayu di negeri Perlis telah berjaya mempengaruhi raja dan elit Melayu Perlis. Dakyah ini mudah diterima oleh penduduk Melayu Perlis yang rata-ratanya masyarakat petani yang berpegang kepada nilai tradisi taat setia kepada raja dan pemimpin masyarakat. ${ }^{8}$ Keadaan ini menyumbang kepada kestabilan politik British di negeri Perlis sehinggalah Perang Dunia ke-2, apabila tiada reaksi penentangan terhadap pertadbiran British sama ada daripada raja dan elit Melayu mahupun penduduk tempatan. British meletakan kawalan ke atas anak negeri dengan mengikat raja dan pemimpin Melayu dengan pemberian ganjaran. Seperti mana disebut oleh Chandra: ${ }^{89}$

....istana-istana indah, pangkat-pangkat tinggi serta kedudukan tinggi - semuanya sama saja matlamatnya - untuk mendapat taatsetia para pemerintah Melayu supaya taat setia buta rakyat akan tertumpu ke arah kolonialisme British..$^{90}$

Tidak dinafikan bahawa Perjanjian Perlis-British pada 28 April, 1930 telah memperakukan kewujudan kerajaan Perlis di bawah pemerintahan keluarga Jamalullail. Perjanjian ini sekaligus menamatkan kebimbangan Raja Syed Alwi Jamalullail terhadap kemungkinan Perlis akan diserapkan kembali ke dalam pentadbiran Kedah. Tetapi perjanjian tersebut telah mengecilkan bidang kuasa raja dalam urusan politik dan pemerintahan, apabila raja Perlis tidak lagi bebas untuk mengadakan hubungan politik dengan kuasa luar. ${ }^{91}$

Selain itu, raja Perlis bukan sahaja perlu mendapat nasihat daripada Penasihat Britsh dalam urusan pentadbiran negeri, tetapi juga berkongsi kuasa dan pengaruh dengan golongan elit Melayu yang menjadi ahli Majlis Mesyuarat Negeri dan yang memegang jawatan penting dalam pentadbiran kerajaan negeri. Pihak British telah berjaya meletakkan kawalan ke atas penduduk negeri Perlis bukan sahaja dengan cara mengikat raja dan elit dengan pemberian ganjaran dan jawatan tetapi juga dengan cara mengasingkan agama Islam daripada politik dan pemerintahan. ${ }^{92}$ Pengasingan agama daripada politik dan pemerintahan sebenarnya memberi kesan kepada perkembangan gerakan Islah di Perlis sekitar tahun 1920-an dan 1930-an apabila perkara yang diislahkan hanya perkara "ibadat", dan bukannya politik dan pemerintahan. ${ }^{93}$ Oleh sebab itu, gerakan Islah di Perlis tidak menyumbang kepada kesedaran politik masyarakat Melayu Islam di Perlis. 


\section{Kesimpulan}

Naungan tidak rasmi British ke atas Perlis sejak termeterainya Perjanjian Bangkok 1909 memastikan kedaulatan Perlis sebagai sebuah negeri berterusan. Pemerintah Perlis, Raja Syed Alwi sebenarnya berpeluang besar untuk menafikan minat British ke atas Perlis apabila negeri itu berupaya melunaskan hutangnya dengan Negeri Melayu Bersekutu pada penghujung 1929. Namun atas dasar pengukuhan kuasa daripada ancaman dalaman dan luaran serta memandang tinggi terhadap kekuasaan British, Raja Syed Alwi memilih untuk menjalinkan hubungan rasmi dengan British melalui Perjanjian Perlis- British 1930.

Walaupun Perjanjian British-Perlis 1930 menandakan berakhirnya kedaulatan Perlis sebagai sebuah negeri yang merdeka sebaliknya berada di bawah naungan kerajaan British, namun daripada satu segi perjanjian itu telah mengukuhkan lagi kedudukan Syed Alwi sebagai raja Perlis. Perjanjian Perlis-British 1930 telah memberi implikasi yang besar kepada kedudukan raja Perlis sebagai ketua negeri. Perjanjian tersebut telah menyempitkan bidang kuasa raja Perlis dalam hal ehwal pentadbiran negeri dan meningkatkan kawalan Penasihat British terhadap politik dan pentadbiran Perlis. Perjanjian tersebut telah mengangkat martabat elit Melayu dalam urusan pentadbiran negeri melalui keahlian mereka dalam Majlis Mesyuarat Negeri. Raja Perlis bukan sahaja perlu kepada sokongan Penasihat British tetapi juga elit Melayu yang semakin berpengaruh dalam memutuskan sesuatu keputusan.

Hubungan dan kerjasama yang baik antara elit Melayu dengan pegawai British menyebabkan mereka berada dalam posisi yang selesa sehingga mereka tidak menyedari bahawa mereka telah menjadi alat untuk membendung kesedaran politik dalam kalangan rakyat. Tiupan angin perubahan yang cuba dibawa oleh gerakan Islah Islam gagal menarik perhatian rakyat Perlis sebaliknya ia menarik perhatian golongan elit pentadbir Melayu dalam melakukan Islah dalam hal ehwal amalan agama sahaja. Tidak dapat dinafikan hubungan tradisional raja dan elit Melayu dengan rakyat menjadi senjata utuh kepada pihak British untuk menjayakan misi dan visi pemerintahannya di Negeri Perlis.

\section{Nota}

1 Kobkua Suwannathat-Pian, Thai Malay Relation, Singapore: East Asian Historical Monographs, 1988. hlm. 90-92

2 Ahmad Ismail dan Yazid Mat, Perlis Indera Kayangan, Kangar; Perbadanan Perpustakaan Awam Perlis, 1992, hlm 39. Lihat juga Mohd Isa Othman, Hubungan Kesultanan Kesultanan Kedah Dengan Sejarah Perlis Indera 
Kayangan, Unit Koleksi Negeri Perlis, hlm. 3, dan Politik Tradisional Kedah 1681-1942, Kuala Lumpur: Dewan Bahasa dan Pustaka, 1990, hlm, 29-33. Perjanjian Bangkok ditandatangani di Bangkok pada 10 Mac 1909. Fasal Pertama Perjanjian menyentuh penyerahan Kelantan, Terangganu, Kedah, Perlis, dan Pulau-pulau bersebelahan kepada pihak British. Kerajaan Siam menyerahkan kepada Kerajaan British segala hak dan apa-apa jua kekuasaan, naungan, pentadbiran dan kawalan yang dimilikinya ke atas negeri Kelantan, Terangganu, Kedah, Perlis dan Pulau-pulau bersebelahan. Lihat Perjanjian \& Dokumen Lama Malaysia, Institut Terjemahan Negara Malaysia, Kuala Lumpur, 2008, hlm. 50. Menjadi naungan tidak rasmi kepada pihak British perlu mendapat persetujuan dan tandatangan daripada raja Perlis.

5 Simon C. Smith, British Relation With the Malay Rulers from Decentralization to Malayan Independence 1930-1957, Kuala Lumpur: Oxford University Press, 1955, hlm. 11 dan 16.

6 Lanjutan daripada Perjanjian Inggeris - Siam 1909, di mana Kerajaan Negeri Melayu Bersekutu akan mengambil alih baki hutang daripada Negeri-negeri Melayu Utara yang merupakan bekas wilayah jajahan Siam. Sepertimana yang tersebut dalam Perjanjian hutang Perlis Siam pada tahun 1905 dan 1907, bahawa perkhidmatan Penasihat Kewangan adalah sehingga hutang selesai dibayar seperuhnya. Lihat J.de V. Allen, A.J. Stockwell, L.R. Wright, A Collection Of Treaties And Other Documents Affecting The States Of Malaya, London: Oceana Publication, Inc, 1981, hlm. 410-411 dan 415-417.

British perlu memdapat persetujan daripada pemerintah tempatan melalui perjanjian rasmi untuk mengesahkan perlantikan pengawai penasihatnya ke dalam pentadbiran negeri-negeri Melayu. Rupert Emerson, Malaysia, Kuala Lumpur : Dewan Bahasa dan Pustaka, 1974, hlm. 301. Maxwell, "Secret Memorandum Upon The Futere Of The States Of Perlis" 3 April 1915, Papers of John Hamer (Tidak diterbitkan), MSSM Ind. Ocn. S316. Box 1 File 3, dalam Julie Tang Su Chin, Sejarah Kerajaan Perlis 18411957, MBRAS, 2002, hlm. 179. Ibid

12 Ibid

13 Ibid

14 Mohd Asyraf Ibrahim, Gagasan Melayu Bersatu 1945-57, Bangi: Universiti Kebangsaan Malaysia, 2004, hlm. 27. Sebenarnya telah ada usaha untuk menyatukan Negeri Melayu Tidak Bersekutu dengan Negeri Melayu Bersekutu sejak tahun 1920an lagi. Maxwell telah mengetuai Jawatankuasa Pengagihan Kuasa Pusat memperakukan bahawa pengagihan kuasa pusat adalah perlu bagi mengukuhkan kedudukan Residen, Sultan dan Majlis Mesyuarat Negeri. Jawatankuasa George Maxwell juga mengkaji kedudukan kewangan dalam konteks dasar desentralisasi. Mereka berpendapat bahawa pengagihan kuasa hanya dapat berjalan apabila kerajaan-kerajaan negeri diberi kuasa penuh untuk mengawal soalsoal kewangan. Jawatankuasa Pengagihan Kuasa Pusat telah membuat 
beberapa cadangan. Antaranya ialah, kuasa Residen ditambah supaya seimbang dengan kuasa Residen Jeneral dan kuasa pengawalan beberapa jabatan seperti Jabatan Pertanian, Jabatan Perhutanan, Jabatan Polis dan Jabatan Perubatan dipindahkan kepada kawalan kerajaan negeri. Cadangan-cadangan pengagihan kuasa pusat masih mempunyai beberapa kelemahan. Misalnya, jawatankuasa tersebut tidak cuba memulihkan kedudukan dan pengaruh politik sultan-sultan. Malah jawatan Maxwell sebagai Ketua Setiausaha mengatasi kuasa Raja-Raja Melayu. Selain itu, kedudukan Maxwell sebagai Ketua Setiausaha telah mencetuskan konflik dengan Sir Lawrence Gullemard, Pesuruhjaya Tinggi Tanah Melayu dan konflik tersebut menjejaskan usaha ke arah perlaksanaan "Decentralisasi". Philip Loh Fook-Seng, Malay Precedence And The Federal Formula In The Federated Malay States, 1909 to 1939, JMBRAS, vol 45, 1972, hlm. 2950. Lihat juga Yeo Kim Wah, The Guillemard - Maxwell Power Struggle, 1921-1925, JMBRAS, vol 54. 1981, hlm. 48-64. Rennie Smith, The Future Of Malaya, Pacific Affair, vol. 6, no. 7, University of Colombia, hlm. 394-398. Usaha menyerapkan Perlis ke dalam Kedah tentutanya mendapat tentangan daripada pemerintah Perlis yang selama ini berusaha untuk mengekalkan kerajaan Perlis sebagai negeri yang berasingan daripada Kedah.

Lihat Mohd Isa Othman, Politik Tradisional Kedah 1681-1942, hlm. 89-95. Lihat juga Abdullah Zakaria bin Ghazali, Sejarah Gerakan Politik Awal di Kedah, Kuala Lumpur: Universiti Malaya, 2006, hlm. 8-15. Surat Allen kepada Penasihat Kedah 24 Julai 1930, AP 120/49.

Perlis Annual Report 1928, hlm. 60.

Penasihat Kedah kepada Penasihat Perlis 18 Oktober 1930. HC 149/49. Berlaku kemelesatan ekonomi dunia sekitar tahun 1920-an dan selain negeri Perlis tidak mempunyai hasil yang banyak untuk membayar gaji pegawai perkhidmtan negeri. Rupert Emerson, Malaysia, hlm. 388.

Ibid Philip Loh Fook-Seng, Malay Precedence And The Federal Formula In The Federated Malay States, 1909 to 1939, hlm. 40. Julie Tang Su Chin, Sejarah Kerajaan Perlis 1841-1957, hlm. 171-177. Raja Syed Alwi kepada Clifford, 21 Januari 1929, HC 472/ 47. Abdul Rahman Haji Ismail, Silat dan Silau Imperialisme British di Tanah Melayu; Langkah dan Buah, dalam Kolonialisme di Malaysia dan Negaranegara Lain, Kuala Lumpur :Fajar Bakti, 1990, hlm. 83. Shukur Mat dan Syed Alwi, Pemimpin Dalam Tiga Zaman 1905-1943, Kajian Sejarah Negeri Perlis, 1978, Koleksi Indera Kayangan, Perpustakaan Awam Negeri Perlis, tidak diterbitkan, hlm. 5. J.de V. Allen, A.J. Stockwell dan L.R. Wright, A Collection Of Traties And Other Documents Affecting The States Of Malaysia 1761-1963, Volume 1, London : Oceana Publication, Inc, 1981, hlm. 442. Ibid, hlm. 441

30 Minit Mesyurat Majlis Mesyuarat Negeri Perlis, 3 Mei 1930. Koleksi Indera Kayangan, Perpustakaan Awam Negeri Perlis. 
31 Syed Hamzah adalah adik kepada Syed Mahmud dan saudara tiri kepada Raja Syed Alwi. Maklumat lanjut lihat Syed Muhammad Shaiful bin Syed Abdul Aziz Jamalullail, Jamalullail, tidak diterbit, Muzium Kota Kayang, 2003. Lihat juga Ahmad Ismail dan Yazid Mat, Perlis Indera Kayangan, Sejarah Pembentukan Sebuah Negeri Yang Berdaulat, hlm. 85-86.

32 Minit Mesyuarat 15 April 1912, CO 273 1098a. 386/22831

33 Julie Tang Su Chin, Sejarah Kerajaan Perlis 1841-1957, hlm. 234

$34 \quad$ Ibid

35 de V. Allen, A.J. Stockwell dan L.R. Wright, A Collection Of Traties And Other Documents Affecting The States Of Malaysia 1761-1963, Volume 1, hlm. 441

36 Caldecott kepada Cunliffe-Lister, 25 Julai 1934, CO717. 107/33411

37 Syed Hamzah beranggapan sistem persekolahan di sekolah-sekolah Melayu perlu diperbaiki dengan memberi pendedahan kepada muridmurid pelajaran yang boleh memperbaiki kehidupan mereka sehari-hari. Syed Hamzah juga telah dilantik memjadi Pengerusi Jawatankuasa Pelajaran yang ditubuhkan pada tahun 1932. Syed Hamzah juga bertanggungjawab menggantikan pelajaran rumi kepada pelajaran jawi dan karangan jawi bagi darjah satu dan darjah dua, sementara pelajaran rumi akan dimulai pada darjah tiga. Lihat Minit Mesyuarat Majlis Mesyuarat Negeri Perlis 1932, Koleksi Indera Kayangan, Perpustakaan Awam Perlis. Lihat juga Perlis Annual Report, 1932, hlm. 81. Ahmad Ismail dan Yazid Mat, Perlis Indera Kayangan: Sejarah Pembentukan Sebuah Negeri Berdaulat, hlm. 148-149.

38 Syed Hamzah juga memberi sumbangan dalam pembinaan Masjid Alwi Kangar, dan terlibat sebagai Yang Di-Pertua Pengusaha Masjid. Lihat Sheikh Ahmad, Catatan Dato' Sheikh Ahmad bin Mohd Hashim, Koleksi Indera Kayangan, Perpustakaan Awam Negeri Perlis, Tidak diterbitkan, hlm. 9-12. Lihat juga Ahmad Ismail dan Yazid Mat, Perlis Indera Kayangan: Sejarah Pembentukan Sebuah Negeri Berdaulat, hlm. 149-150.

39 Temubual dengan Cikgu Zain Othman, 28/7/2012, dan Mak Mah, 25/8/2012. Cikgu Zain dan Mak Mah mempunyai hubungan adikkakak dan amat mengenali kerabat di Raja Perlis. Mak Mah merupakan pengasuh kepada Tuanku Syed Hassan Jamalullail iaitu putera kepada Syed Harun Jamalullail (Tuanku Syed Putra), Cikgu Zain juga mengenali Syed Sofian, iaitu putera kepada Syed Hamzah. Mengikut Cikgu Zain, Sofian Club terlibat dalam aktiviti perjudian.

40 Temubual dengan Cikgu Zain Othman, 28/7/2012. Mengikut Cikgu Zain, antara aktiviti kumpulan Tuan Bulat ialah mencuri lembu dan memaksa penduduk menyertai kumpulan mereka untuk mendapat perlindungan. Kongsi gelap Tuan Bulat juga mempunyai hubungan dengan salah satu kumpulan kongsi gelap di Pulau Pinang, sama ada kumpulan bendera putih atau kumpulan bendera merah. Ahli kongsi gelap Tuan Bulat turut disertai oleh kakitangan kerajaan seperti Polis, pengawai penjara, kakitangan mahkamah, penghulu dan dikaitkan dengan kerabat diraja Perlis yang terlibat dalam perebutan takhta. Maklumat lanjut mengenai Kongsi gelap Tuan Bulat, lihat, Mahani Musa, Kongsi Gelap Melayu Di 
Negeri-Negeri Utara Pantai Barat Semenanjung Tanah Melayu 1821-1940an, MBRAS monograph No. 36. 2003, hlm. 153-160. Menurut cikgu Zain Othman, Kumpulan ini mempunyai hubungan dengan kerabat diraja Perlis. Cikgu Zain menghubungkaitkan kumpulan Tuan Bulat dengan Syed Syed Mansur Al-Jafri, yang lebih dikenali dengan panggilan "Tuan Bulat". Sebab itu kumpulan ini dinamakan "Tuan Bulat". Syed Mansur Al-Jafri juga merupakan salah seorang pembesar yang dihantar oleh Sultan Kedah ke Perlis dalam usaha menyerapkan semula Perlis ke dalam Kedah pada tahun 1897. Lihat Ahmad Ismail dan Yazid Mat, Perlis Indera Kayangan : Sejarah Pembentukan Sebuah Negeri Berdaulat, hlm. 77-79. Puteri kepada Syed Mansur Al Jafri iaitu Sharifah Salma berkahwin dengan Syed Hussain, iaitu putera Syed Safi Jamalullail, Raja Perlis yang ke-3. Syed Hussein ialah putera ke-4 Raja Syed Safi dan adik seibu kepada Syed Hamzah. Lihat juga, Syed Mohummad Shaiful Bin Syed Abdul Aziz Jamalullail. Jamalullail. Syed Hussain juga diketepikan perlantikan sebagai raja Perlis bagi menggantikan Syed Alwi. Lihat Julie Tang Su Chin, Sejarah Kerajaan Perlis 1841-1957, hlm. 237. Apa yang menarik Syed Mansur pernah menjawat jawatan Ketua Hakim Mahkamah Kedah dan Syed Hussain Magistret Kedua Perlis. Lihat juga Surat Menyurat Sultan Abdul Hamid T.H1304-1312, T. M 1886-1894, Buku No. 2, hlm. 191 dan 201, Panggilan "Tuan Bulat" tertera kepada surat tersebut. Namun hubungkait Kumpulan Tuan Bulat dengan Syed Mansur Al-Jafri tidak dapat dibuktikan kesahihannya. Temubual dengan Cikgu Zain Othman, 28 / 7 / 2012, Lihat juga, Syed Mohummad Shaiful Bin Syed Abdul Aziz Jamalullail. Jamalullail. Lihat juga Mahani Musa, Kongsi Gelap Melayu Di Negeri-Negeri Utara Pantai Barat Semenanjung Tanah Melayu 1821-1940-an, hlm. 159. Mahani Musa, Kongsi Gelap Melayu Di Negeri-Negeri Utara Pantai Barat Semenanjung Tanah Melayu 1821-1940-an, hlm. 159. Temubual dengan Cikgu Zain Othman, 28/7/2012

Fail B.M.A, Ps. 134. 1946. Arkib Negara Cawangan Alor Setar.

Caldecott kepada Cunliffe-Lister, 25 Julai 1934, CO717. 107/33411

Fail SUK, 31 Desember 1936. A.P 750/1355

Julie Tang Su Chin, Sejarah Kerajaan Perlis 1841-1957, hlm. 238.

Sheikh Ahmad, Catatan Dato' Sheikh Ahmad bin Mohd Hashim, hlm. 16. Tuan Haji Ahmad merupakan orang yang bertanggugjawab mempengaruhi Raja Syed Alwi untuk melantik Syed Hassan sebagai "Bakal Raja Perlis" berbanding Syed Hamzah. Lihat Ahmad Ismail dan Yazid Mat, Perlis Indera Kayangan: Sejarah Pembentukan Sebuah Negeri Berdaulat, hlm. 152.

Syed Hassan Jamalullail ialah putera kepada Syed Mahmud iaitu Raja Muda Perlis (meninggal di Alor Setar). Syed Mahmud abang kandung kepada Syed Hamzah dan Syed Hussain. Lihat, Lihat Syed Mohummad Shaiful Bin Syed Abdul Aziz Jamalullail. Jamalullail.

50 Sheikh Ahmad, Catatan Dato' Sheikh Ahmad bin Mohd Hashim, hlm. 16-18

51 Ibid.

52 Julie Tang Su Chin, Sejarah Kerajaan Perlis 1841-1957, hlm. 245 
53 Meninggal dunia di hospital Alor Setar kerana penyakit dalam telinga. Lihat Sheikh Ahmad, Catatan Dato' Sheikh Ahmad bin Mohd Hashim, hlm. 17.

54 Untuk penjelasan lanjut mengenai isu perlantikan bakal raja lihat Julie Tang Su Chin, Sejarah Kerajaan Perlis 1841-1957, hlm. 211-277. Berdasarkan pertaliannya dengan Raja Syed Alwi, Syed Hamzah merupakan waris yang paling hampir. Tambahan pula Raja Syed Alwi tidak mempunyai anak lelaki. Syed Harun adalah putera kepada Syed Hassan iaitu "Bakal Raja Perlis" yang meninggal pada tahun 1935. Syed Harun lebih dikenali dengan panggilan "Syed Putra". Sheikh Ahmad, Catatan Dato' Sheikh Ahmad bin Mohd Hashim, hlm. 17. Temubual dengan Cikgu Zain Othman, 28 / 7 / 2012. J.de V. Allen, A.J. Stockwell dan L.R. Wright, A Collection Of Traties And Other Documents Affecting The States Of Malaysia 1761-1963, hlm. 421. Kuasa Penasihat British sebenarnya meliputi kuasa eksekutif, perundangan dan kehakiman, malah terlibat dalam memberi "persetujuan" kepada pelantikan "Bakal Raja Perlis". Lihat Julie Tang Su Chin, Sejarah Kerajaan Perlis 1841-1957, hlm. 184-185. Hugh Clifford to L.S. Amery, 24 January 1929, CO 717/63 no. 62349/1929. Lihat kajian Sharom Ahmat, Kedah: Tradition and Change In A Malay State, A Study Of The Economic And Political Development 1878-1923. MBRAS, Kuala Lumpur, 1984. Kedah mencapai kemajuan semasa pemerintahan Sultan Abdul Hamid. J.V. de Allen, The elephant and mousedeer - a new version of AngloKedah relation 1905-1915. JMBRAS 40(1). 1968, hlm 60-81. Allen menyebut bahawa "...terdapat pentadbiran pusat yang tersusun terdiri dari orang Melayu dan sebahagian mereka mempunyai kemampuan yang tinggi dalam pentadbiran kerajaan". Mohd Isa Othman, Sejarah Malaysia (1800-1963), Petaling Jaya: Utusan Publication \& Distributors Sdn bhd, 2002, hlm. 135-139. Untuk mengetahui lebih lanjut mengenai draf Perjanjian Perlis British 1930 lihat kajian Julie Tang Su Chin, Sejarah Kerajaan Perlis 1841-1957, hlm. 171-210. J.de V. Allen, A.J. Stockwell dan L.R. Wright, A Collection Of Traties And Other Documents Affecting The States Of Malaysia 1761-1963, hlm. 422 Ibid.

68 Ibid.

69 Untuk melihat perincian Perlembagaan Johor 1895, lihat J.de V. Allen, A.J. Stockwell dan L.R. Wright, A Collection Of Traties And Other Documents Affecting The States Of Malaysia 1761-1963, hlm. 77-101. Sebenarnya Perlembagaan Johor telah menjadi contoh kepada Negeri Melayu Tidak Bersekutu terutamanya Perlis dalam menyusun menyusun Pentadbiran Negeri. Tentunya Raja Syed Alwi menyedari kejayaan Sultan Johor dalam momodenkan pentadbiran Johor. Apatah lagi Raja Syed Alwi menghadiri DURBAR di Singapura pada tahun 1929 dan tentunya berkesempatan 
berbincang dengan Sultan Negeri Melayu yang lain, khususnya Johor dan Kedah.

Ibid., hlm. 175-176, Lihat juga Mohd Isa Othman, Zaman Penjajahan British, Pengalaman Kedah Perlis, Kuala Lumpur: Utusan Publications, 2001, hlm 183-243, dan Julie Tang Su Chin, Sejarah Kerajaan Perlis 1841-1957, hlm. 171-177.

71 Simon C. Smith, British Relations with the Malay Ruler from Decentralization to Malayan Independence 1930-1957, hlm. 26-29.

72 Lihat kajian Oong Hak Ching, Penggubalan Dasar British terhadap Tanah Melayu Semasa Perang Dunia Kedua, Jebat (24). 1996, hlm. 85-100. Bilangan orang Cina dan India telah melebihi penduduk keturunan Melayu dalam tahun 1931, dan pada tahun 1941 mereka membentuk hampir 60 peratus daripada jumlah penduduk Tanah Melayu dan sebahagian besar mereka menetap di Negeri-negeri Selat.Lihat juga Rupert Emerson, Malaysia, hlm. 239 dan 330, lihat juga, K.J Ratnam, Paham Perkauman dan Proses Politik di Malaya, Kuala Lumpur: Universiti Malaya, 1969, hlm. 2-15.

Seperti mana yang disuarakan oleh Persatuan Melayu Selangor dalam akhbar The Malay Mail, 11 Mac 1924, mengenai cadangan penubuhan dana pendidikan bagi membantu pelajar Melayu yang miskin. Rungutan mengenai pelajar Melayu yang ketinggal dalam pendidikan tinggi telah disuarakan oleh Presiden Persatuan Guru Melayu dalam persidangan tahunan pada tahun 1929. Lihat The Malay Tribune 1929. Misalnya Majalah Guru keluaran Jun 1929, Anaknegeri menulis... "Melayu... apa ada? ... Maka di dalam sorak dan raungan bangsa-bangsa Cina, Keling dan keturunan Portugis (menuntut kedudukan yang sama dengan orang-orang Melayu) itu sekali-sekali kedengaran juga bunyi orang Inggeris dan pegawai Inggeris menggingatkan mereka itu yang negeri ini negeri Melayu dan orang Inggeris dijemput datang ke mari.... Sebagai contoh Seperti akhbar The Malay Mail, The Malay Tribune, Utusan Melayu.

76 Sehingga tahun 1946, hanya 13 orang murid sahaja yang berjaya memasuki darjah VI, 10 lelaki dan tiga perempuan. Lihat Perlis Annual Report 1946, Malay School.

77 Berdasarkan senarai pelajar menerima latihan di luar, sama ada Sultan Abdul Hamid College, Francis Light College, Penang Free School, dan Malay College pada tahun 1945, sebahagian besar adalah terdiri daripada kerabat diraja dan daripada keluarga elit Melayu. Semua pelajar berkenaan mendapat biasiswa, dan akan ditarik balik jika gagal melepasi had kelayakan. Walaupun begitu, kerabat diraja Perlis masih boleh merayu sekiranya gagal, dan biasanya rayuannya diterima.Lihat laporan BMA 118/1945. Minit Mesyuarat Majlis Mesyuarat Negeri, tahun 1934, Simpanan Koleksi Indera Kayangan, Perpustakaan Awam Perlis.

79 Buku Cenderamata, Sambutan 100 tahun Sekolah Kebangsaan Dato Wan Ahmad.

80 Ramli Ismail, Tokoh Tempatan, Dato' Haji Wan Ahmad Wan Daud, Warisan Indera Kayangan, Kangar, Perbadanan Perpustakaan Awam Perlis, 
1990, hlm 26. Ahmad Haji Kassim, bersama Wan Ahmad Wan Daud dan Syed Alwi pernah belajar bersama di Penang Free School dan mereka lulus dalam peperiksaan Senior Cambridge.

Julie Tang Su Chin, Sejarah Kerajaan Perlis 1841-1957, hlm. 242, Lihat juga Ahmad Ismail dan Yazid Mat, Perlis Indera Kayangan: Sejarah Pembentukan Sebuah Negeri Berdaulat, hlm. 154-155. Penjelasan lanjut lihat Sheikh Ahmad, Catatan Dato' Sheikh Ahmad bin Mohd Hashim, hlm. 16-18. J.de V. Allen, A.J. Stockwell dan L.R. Wright, A Collection Of Traties And Other Documents Affecting The States Of Malaysia 1761-196, hlm. 421. Penjelasan lanjut mengenai hutang Raja Perlis (Syed Alwi) dan kerabat raja lihat Julie Tang Su Chin, Sejarah Kerajaan Perlis 1841-1957, hlm. 205209. Sebahagian besar hutang dengan ceti Jagat Singh dianggap selesai apabila Jagat Singh diputuskan oleh Majlis Mesyuarat Negeri dihukum "buang negeri". Nordin Selat, Kelas Menengah Pentadbir Melayu, Kuala Lumpur: Utusan Melayu, 1976, hlm. 105.

Antara jabatan pentig ialah Jabatan Perbendaharaan yang diketuai oleh Wan Ahmad Wan Daud sebelum dilantik menjadi Ahli Majlis Mesyuarat Negeri pada tahun 1938, Jabatan Tanah dan Galin yang diketuai oleh Syed Hamzah (sebelumnya diketuai oleh Tunku Abdullah, dari Kedah tetapi dilucutkan jawatan kerana didapati bersalah kerana bersubahat dalam kes hubungan sulit seorang wanita Islam dengan lelaki bukan Islam) dan kemudiannya diganti oleh Abdullah bin Ahmad. Lihat Minit Mesyuarat 20 November 1913, CO 273, 1098a. 409/3760, Minit Mesyuarat 9 Februari 1914. C0273 1098a. 410/16073. Minit Mesyuarat 4 Mei 1914, CO 2731089 a. 411/26298. Lihat juga Minit Mesyuarat Majlis Mesyuarat Perlis 1932, Koleksi Indera Kayangan, Perpustakaan Awam Perlis.

Ahmad Ismail, Seri Indra Kayangan, Sejarah Negeri Perlis, 1361 Masihi, Koleksi Indera Kayangan, Perpustakaan Awam Negeri Perlis. Tidak diterbitkan, hlm. 25.

$88 \quad$ Mengikut Frank Swettenham, “Ada jurang perbezaan yang luas di antara kelas pemerintah dengan rakyat. Raja-raja dan ketua-ketua memerintah, rakyat mentaati. Rakyat tidak berikhtiar apa-apa, peranan mereka sekadar menyempurnakan keinginan raia atau ketua yang berkuasa ke atas mereka, dengan anggapan bahawa suruhan pemerintah mesti dipatuhi semua orang". Lihat Frank Swettenham, Footprints in Malaya, London: Hutchinson and Company, 1941, hlm. 48. Lihat juga Frank Swettenham, The Real Malay, London: J. Lane 1899, hlm. 17.

Raja Syed Alwi juga mendapat Istana di Arau, dan menuntut pembinaan Istana di Arau pada tahun 1934. Lihat surat Raja kepada Venables 1934, PP 446/51.

$90 \quad$ Chandra Muzaffar, Pelindung?: Satu Kajian Tentang Konsep dan Amalan dalam Hubungan antara Pemimpin dan Pengikut dalam Masyarakat Melayu, Aliran Kesedaran Negara, 1992, hlm. 63. 
Lihat perkara ke-2, Perjanjian Perlis British 1930 dalam J.de V. Allen, A.J. Stockwell dan L.R. Wright, A Collection Of Traties And Other Documents Affecting The States Of Malaysia 1761-1963, hlm. 421. British berkuasa menasihat segala hal ehwal pentadbiran kecuali agama Islam dan adat istiadat Melayu merupakan petunjuk yang jelas pemisahan urusan pemerintahan daripada agama Islam. Lihat J.de V. Allen, A.J. Stockwell dan L.R. Wright, A Collection Of Treties And Other Documents Affecting The States Of Malaysia 1761-1963, hlm. 421. Langkah untuk menjayakan pemisahan ini ialah melantik mereka yang berpendidikan Inggeris memegang jawatan utama pentadbiran negeri dan mempengaruhi Raja-raja Melayu yang merupakan ketua agama Islam (berdasarkan Perjanjian Perlis British 1930) menghantar putera puteri mereka ke sekolah aliran Inggeris. Mengikut Abdul Rahman, "Bakal-bakal Raja diasuh dengan nilai-nilai sekular untuk menjadi pengawal agama, bukannya pengamal dan pemelihara agama dalam erti kata sebenarnya. Mereka dijadikan pemerintah agama, bukannya ilmuan yang memerintah dengan berpandukan agama. Lihat Abdul Rahman Haji Ismail, Silat dan Silau Imperialisme British di Tanah Melayu; Langkah dan Buah, dalam Kolonialisme di Malaysia dan Negara-negara Lain, hlm. 83. Rahman Haji Abdullah, Gerakan Islah Di Perlis: Sejarah dan Pemikiran, Kuala Lumpur :Penerbitan Pena Sdn. Bhd, 1989, hlm. 20-24. Lihat juga, Shukur Mat, As Sunnah Di Perlis, Kangar: MediaONE Publication, 2012, hlm. 33-39. 